Warda, I.M. • B. Waluyo

\title{
Kompatibilitas persilangan interspesifik pada spesies cabai
}

Sari. Peningkatan produksi cabai (Capsicum sp.) dapat dilakukan dengan melakukan diversifikasi jenis baru dari hasil persilangan antar spesies. Tujuan penelitian ialah untuk mempelajari kompatibilitas pada penyerbukan sendiri dan penyerbukan silang buatan interspesies. Penelitian dilaksanakan pada Januari 2020 - Juni 2020. Bahan yang digunakan ialah 4 spesies cabai. Persilangan disusun berdasarkan rancangan perkawinan dialil lengkap. Terdapat 16 kombinasi persilangan. Perbedaan karakter kuantitatif penyerbukan sendiri dan silang diuji menggunakan uji t $5 \%$. Penyerbukan sendiri pada setiap spesies memiliki kompatibilitas penuh dengan persentase pembentukan buah yaitu 100\%. Persilangan antara C. annuum Cann(B)-CYM2-151-3 x C. baccatum Cbac-09(S), C. frutescens Cfru-03(4) x C. annuum Cann(B)-CYM2-151-3 dan C. frutescens Cfru-03(4) x C. baccatum Cbac-09(S) memiliki kompatibilitas penuh dengan persentase $65 \%$, 50\% dan 85\%. Persilangan antara C. annuum Cann(B)-CYM2-151-3 x C. frutescens Cfru-03(4), C. frutescens Cfru-03(4) $x$ C. chinense (Cchi-01) memiliki kompatibilitas sebagian dengan persentase sebesar $48 \%$ dan $46 \%$. Inkompatibilitas terjadi pada persilangan C. annuum (Cann(B)-CYM2-151-3) x C. chinense (Cchi-01), C. baccatum (Cbac-09(S)) x C. annuum (Cann(B)-CYM2-151-3), C. baccatum (Cbac-09(S)) x C. frutescens (Cfru-03(4), C. baccatum (Cbac-09(S)) x C. chinense (Cchi-01), C. chinense (Cchi-01) x C. annuum (Cann(B)-CYM2-151-3), C. chinense (Cchi-01) x C. frutescens (Cfru-03(4)), C. chinense (Cchi-01) x C. baccatum (Cbac-09(S)).

Kata kunci: C. annuum - C. baccatum - C. chinense - C. frutescens - Persilangan.

\section{Compatibility of interspesific crosses in chilli}

\begin{abstract}
Production of chili (Capsicum sp.) can be increased by diversifying new types of crosses between species. The research objective was to study the compatibility of self-pollination and crosspollination between species. This research was conducted in Januari 2020 - Juni 2020. The materials were included 4 species of $C$. annuum sp. Crossing of 4 species Capsicum sp. using a dialel design. All selfing of each species showed that percentage of fruit set was $100 \%$. Crosses of C. annuum (Cann (B)CYM2-151-3) x C. baccatum (Cbac-09(S)), C. frutescens (Cfru-03(4)) x C. annuum (Cann (B)-CYM2-151-3) and C. frutescens (Cfru-03(4)) x C. baccatum (Cbac-09(S)) had full compatibility with percentages of $65 \%, 50 \%$, and 85\%, respectively. Crosses between C. annuum (Cann(B)-CYM2-151-3) x C. frutescens (Cfru-03(4)), C. frutescens (Cfru-03(4)) x C. chinense (Cchi-01) had partial compatibility with a percentage of $48 \%$ and $46 \%$. Incompatibilities occured in C. annuum (Cann (B)-CYM2-151-3) x C. chinense (Cchi-01), C. baccatum (Cbac-09(S)) x C. annuum (Cann(B)-CYM2-151-3), C. baccatum (Cbac09(S)) x C. frutescens (Cfru-03(4)), C. baccatum (Cbac-09(S) x C. chinense (Cchi-01), C. chinense (Cchi-01) $\mathrm{x}$ C. annuum (Cann(B)-CYM2-151-3), C. chinense (Cchi-01) x C. frutescens (Cfru-03(4)), C. chinense (Cchi01) x C. baccatum (Cbac-09(S)).
\end{abstract}

Keywords: C. annuum · C. baccatum · C. frutescens · C. chinense $\cdot$ Hybridization

Diterima : 25 Agustus 2020, Disetujui : 12 Desember 2020, Dipublikasikan : 31 Desember 2020 doi: https://doi.org/10.24198/kultivasi.v19i3.29234

Warda, M.W. • B. Waluyo

Jurusan Budidaya Pertanian, Fakultas Pertanian, Universitas Brawijaya Malang

Korespondensi: budiwaluyo@ub.ac.id 


\section{Pendahuluan}

Cabai (Capsicum sp.) merupakan tanaman hortikultura yang potensial untuk dikembangkan di Indonesia, karena manfaatnya yang begitu besar. Manfaat cabai diantaranya sebagai bumbu dapur, industri, dan obat-obatan (Shandila et al., 2019). Cabai juga digunakan sebagai penguat makanan seperti sambal (Waskito et al., 2018) Lebih dari 100 spesies Capsicum telah teridentifikasi, lima diantaranya telah dibudidayakan, yaitu C. annuum, C. chinense, C. frutescens, C. baccatum, dan C. pubescens (Undang et al., 2015). Cabai segar sebagian besar terdiri dari air (92\%), sisanya adalah karbohidrat dan sejumlah kecil protein dan lemak. Dalam 100 gram cabai mengandung 31 kalori; 92\% air; 1 gram protein; 6 gram karbohidrat; 4,2 gram gula; 2,1 gram serat; 0,3 gram lemak; selain itu juga mengandung vitamin C yang sangat tinggi (Arnason, 2019). Kandungan vitamin $\mathrm{C}$ pada tiap $100 \mathrm{~g}$ cabai berkisar antara 11,9-195,8 mg dan vitamin A berkisar 20,84-303 IU (Kantar et al., 2016).

Produksi cabai di dunia terus mengalami pertumbuhan selama 20 tahun terakhir. Produksi cabai segar dunia mencapai 36,09 juta ton pada tahun 2017 (FAO, 2019). Terdapat sekitar 126 negara yang membudidayakan cabai. Produksi cabai tertinggi berasal dari Asia, yaitu sebesar 66,5\%, diikuti Amerika sebesar 13,2\%, Eropa 10,4\%, Afrika 9,7\% dan Oceania 0,2\%. Produksi cabai di Indonesia dari tahun 2000 hingga 2017 sebesar 1,37 juta ton (FAO, 2019). Efisiensi teknis yang tinggi penting untuk meningkatkan produksi (Rochayat and Munika, 2015). Peningkatan produksi cabai juga dapat diupayakan dengan program pemuliaan tanaman, salah satunya adalah dengan melakukan persilangan interspesifik (Agustina dan Waluyo, 2017). Persilangan interspesifik adalah persilangan tanaman yang berbeda spesies (Fehr, 1991).

Persilangan interspesifik dilakukan untuk mendapatkan karakter baru yang tidak dimiliki oleh induk tanaman. Persilangan interspesifik juga dapat digunakan untuk menambah keragaman genetik serta memperoleh sifat ketahanan terhadap hama dan penyakit (Fehr dan Hadley, 1980). Selain itu persilangan interspesifik digunakan untuk menghasilkan plasma nutfah baru dan memperluas keragaman genetik pada cabai (Yoon et al., 2006).
Tingkat keberhasilan persilangan antar cabai bervariasi, tergantung dari spesies yang akan disilangkan. Semakin jauh hubungan kekerabatan maka semakin tinggi resiko akan terjadi kegagalan untuk mendapatkan tanaman F1 yang hidup dan fertil (Martins et al., 2015). Perlu adanya keterampilan dalam menyilangkan untuk melakukan persilangan interspesifik karena cabai merupakan tanaman menyerbuk sendiri. Oleh karena itu, perlu dipelajari tentang kompatibilitas persilangan pada persilangan interspesifik pada cabai. Tujuan dari penelitian ini adalah untuk mengetahui kompatibilitas pada persilangan interspesifik antara C. annuum (Cann(B)-CYM2-151-2), C. frutescens (Cfru-03(4)), C. baccatum (Cbac-09(S)), dan C. chinense (Cchi01). Hipotesis dari penelitian ini adalah persilangan interspesifik pada $C$. аппиum (Cann(B)-CYM2-151-2), C. frutescens (Cfru-03(4)), C. baccatum (Cbac-09(S)), dan C. chinense (Cchi01) mempunyai tingkat kompatibilitas yang bervariasi.

\section{Bahan dan Metode}

Penelitian telah dilaksanakan pada bulan Januari - Juni 2020 di Seed and Nursery Industry, Agrotechno Park, Universitas Brawijaya, yang berlokasi di Desa Jatikerto, Kecamatan Kromengan, Kabupaten Malang, Provinsi Jawa Timur. Tempat penelitian berada pada ketinggian $324 \mathrm{~m}$ dpl, dengan suhu minimum $24^{\circ} \mathrm{C}$ dan suhu maksimum $31^{\circ} \mathrm{C}$ yang memiliki rata-rata curah hujan 101-543 mm per tahun. Penelitian ini dilaksanakan pada bulan Januari 2020 - Juni 2020.

Bahan yang digunakan ialah 4 spesies cabai, yaitu C. annuum (Cann(B)-CYM2-151-2), C. frutescens (Cfru-03(4)), C. baccatum (Cbac09(S)), dan C. chinense (Cchi-01), tanah, pupuk kandang, ZA, fertiphospate, $\mathrm{KCl}$, insektisida, dan alkohol. Penelitian dilakukan dengan mengobservasi tingkat kompatibilitas, pengamatan karakter kualitatif, dan kuantitatif buah. Rancangan perkawinan yang digunakan adalah dialel lengkap. Terdapat 16 kombinasi set persilangan. Setiap spesies akan diwakili 12 tanaman sehingga total terdapat 48 tanaman yang akan ditanam secara berkala yang bertujuan untuk menjaga viabilitas polen dan sinkronisasi persilangan.

Perbedaan rata-rata karakter kuantitatif dari hasil penyerbukan sendiri dan persilangan 
dilakukan analisis menggunakan uji t. Dengan rumus sebagai berikut:

$$
t=\frac{\bar{X}_{1}-\bar{X}_{2}}{\sqrt{\frac{S_{1}^{2}}{n_{1}}+\frac{S_{2}^{2}}{n_{2}}}}
$$

Keterangan :

$$
\begin{array}{lll}
\mathrm{t} & = & \mathrm{t} \text { hitung } \\
\mathrm{n}_{1,} \mathrm{n}_{2} & = & \text { jumlah sampel } \\
\mathrm{X}_{1} & = & \text { rata-rata sampel 1 } \\
\mathrm{X}_{2} & = & \text { rata-rata sampel2 }
\end{array}
$$

\section{Hasil dan Pembahasan}

Hasil perhitungan nilai kompatibilitas persilangan antar spesies menunjukkan bahwa persentase keberhasilan pembentukan buah setiap persilangan berbeda-beda. Hasil penyerbukan sendiri masing-masing spesies

\begin{tabular}{|c|c|c|c|}
\hline Kombinasi Persilangan & $\begin{array}{c}\text { Jumlah Bunga Yang } \\
\text { Disilangkan }\end{array}$ & $\begin{array}{c}\text { Jumlah Buah } \\
\text { Jadi }\end{array}$ & $\begin{array}{l}\text { Persentase } \\
\text { Buah Jadi }\end{array}$ \\
\hline C. annuum (Can(B)-CYM2-151-3) $x$ & 20 & 20 & $100 \%$ \\
\hline C. annuum (Can(B)-CYM2-151-3 & & & \\
\hline $\begin{array}{l}\text { C. annuum (Can(B)-CYM2-151-3 x } \\
\text { C. frutescens (Cfru-03(4)) }\end{array}$ & 25 & 12 & $48 \%$ \\
\hline $\begin{array}{l}\text { C. annuum (Can(B)-CYM2-151-3 x } \\
\text { C. baccatum (Cbac-09(S)) }\end{array}$ & 20 & 13 & $65 \%$ \\
\hline $\begin{array}{l}\text { C. annuum (Can(B)-CYM2-151-3 x } \\
\text { C. chinense (Cchi-01) }\end{array}$ & 20 & 0 & $0 \%$ \\
\hline $\begin{array}{l}\text { C. frutescens (Cfru-03(4)) } x \\
\text { C. frutescens (Cfru-03(4)) }\end{array}$ & 20 & 20 & $100 \%$ \\
\hline $\begin{array}{l}\text { C. frutescens (Cfru-03(4)) } \mathrm{x} \\
\text { C. annuum (Can(B)-CYM2-151-3 }\end{array}$ & 20 & 10 & $50 \%$ \\
\hline $\begin{array}{l}\text { C. frutescens (Cfru-03(4)) } \mathrm{x} \\
\text { C. baccatum (Cbac-09(S)) }\end{array}$ & 23 & 19 & $82 \%$ \\
\hline $\begin{array}{l}\text { C. frutescens (Cfru-03(4)) } x \\
\text { C. chinense (Cchi-01) }\end{array}$ & 15 & 7 & $46 \%$ \\
\hline $\begin{array}{l}\text { C. baccatum (Cbac-09(S)) } \mathrm{x} \\
\text { C. baccatum (Cbac-09(S)) }\end{array}$ & 20 & 20 & $100 \%$ \\
\hline $\begin{array}{l}\text { C. baccatum (Cbac-09(S)) } \mathrm{x} \\
\text { C. annuum (Can(B)-CYM2-151-3 }\end{array}$ & 26 & 0 & 0 \\
\hline $\begin{array}{l}\text { C. baccatum (Cbac-09(S)) } \mathrm{x} \\
\text { C. frutescens (Cfru-03(4)) }\end{array}$ & 15 & 0 & 0 \\
\hline $\begin{array}{l}\text { C. baccatum (Cbac-09(S)) x } \\
\text { C. chinense (Cchi-01) }\end{array}$ & 15 & 0 & 0 \\
\hline $\begin{array}{l}\text { C. chinense (Cchi-01) x } \\
\text { C. chinense (Cchi-01) }\end{array}$ & 20 & 20 & $100 \%$ \\
\hline $\begin{array}{l}\text { C. chinense (Cchi-01) x } \\
\text { C. annuum (Can(B)-CYM2-151-3 }\end{array}$ & 15 & 0 & 0 \\
\hline $\begin{array}{l}\text { C. chinense (Cchi-01) } \mathrm{x} \\
\text { C. frutescens (Cfru-03(4)) }\end{array}$ & 20 & 0 & 0 \\
\hline $\begin{array}{l}\text { C. chinense (Cchi-01) } \mathrm{x} \\
\text { C. baccatum (Cbac-09(S)) }\end{array}$ & 15 & 0 & 0 \\
\hline
\end{tabular}
menunjukkan persentase kompatibilitas sebesar $100 \%$ yang artinya persilangan sendiri tersebut kompatibel (Tabel 1).

Tabel 1. Kompatibilitas Persilangan Interspesifik Cabai 
Hasil persilangan tertinggi diperoleh dari hasil penyerbukan sendiri, dimana rata-rata kompatibilitasnya adalah $100 \%$. Hal ini disebabkan adanya kecocokan antara putik dengan benang sari sehingga dapat terjadi pembuahan. Persilangan yang dilakukan pada spesies yang sama pada umumnya akan menghasilkan jumlah dan kualitas biji yang baik (do Rêgo et al., 2011). Hal yang sama juga diungkapkan oleh (Nascimento et al., 2015), persilangan antar spesies yang sama pada umumnya akan lebih mudah menghasilkan biji, dibandingkan persilangan antar spesies.

Pada persilangan $C$. annuum, antara $C$. annuum (Cann(B)-CYM2-151-3) x C. baccatum (Cbac-09(S)) menghasilkan persentase kompatibilitas tertinggi yaitu sebesar 65\%, tetapipersentase kompatibilitas terendah dihasilkan pada kombinasi C. annuum (Cann(B)CYM2-151-3) x C. chinense (Cchi-01), yaitu 0\%. Pada persilangan C. frutescens, jika dilakukan persilangan C. frutescens (Cfru-03(4) $\times$ C. baccatum (Cbac-09(S)) akan menghasilkan persentase kompatibilitas terbesar, yaitu sebesar $82 \%$, sedangkan persilangan antara $C$. frutescens (Cfru-03(4) x C. chinense (Cchi-01) akan memperoleh persentase terendah yaitu sebesar 46\% (Tabel 1). Berbeda halnya jika C. baccatum (Cbac-09(S)) dan C. chinense (Cchi-01) dijadikan tetua betina, hasilnya tidak ada persilangan yang berhasil atau persentase $0 \%$.

Persilangan interspesifik seringkali gagal dikarenakan polen inkompatibel dengan pistil sehingga polen berhenti tumbuh sebelum mencapai ovari. Hal ini disebut dengan pre-zygotic inkompatibel. (Martins et al., 2015), menyebutkan penyebab kegagalan persilangan interspesifik diantaranya adalah lambatnya pertumbuhan tabung serbuk sari menuju ovule dan adanya kematian embrio yang disebabkan oleh degenerasi endosperma, sedangkan menurut Barchenger dan Bosland (2019), inkompatibilitas pada cabai dapat terjadi saat pre-zygotic yaitu ketidaksesuaian polen dan pistil.

Tabel 2. Rata-rata bobot buah hasil penyerbukan sendiri dan hasil penyerbukan silang antar spesies.

\begin{tabular}{llcccc}
\hline Cann(B)- & Rata-Rata Bobot Buah (gr) & $\begin{array}{c}\text { Cann(B)- } \\
\text { CYM2-151-3 }\end{array}$ & Cfru-03(4) & Cbac-09(S) & $\begin{array}{c}\text { Cchi- } \\
03\end{array}$ \\
\hline CYM2-151-3 & P value & 9,76 & 9,58 & 8,96 & - \\
Cfru-03(4) & Rata-Rata Bobot Buah (gr) & - & 0,74 & 0,28 & - \\
& P value & 0,24 & 2,93 & 2,16 & 1,94 \\
Cbac-09(S) & Rata-Rata Bobot Buah (gr) & 18,93 & - & $0,00^{* *}$ & $0,00^{* *}$ \\
& P value & - & - & - & - \\
Cchi-03 & Rata-Rata Bobot Buah (gr) & 5,18 & - & - & - \\
& P value & - & - & - & - \\
\hline
\end{tabular}

Keterangan: $\left({ }^{*}\right)$ : berbeda pada uji t $5 \%,\left(^{* *}\right)$ berbeda pada uji t $1 \%$ antara rata-rata hasil penyerbukan sendiri dan hasil penyerbukan silang antar spesies, (-) : tidak ada data.

Tabel 3. Rata-rata panjang buah hasil penyerbukan sendiri dan hasil penyerbukan silang antar spesies.

\begin{tabular}{llcccc}
\hline Cann(B)- & Rata-Rata Panjang buah (cm) & Cann(B)- & Cfru-03(4) & Cbac-09(S) & Cchi-03 \\
\hline CYM2-151-3 & P value & 11,34 & 10,21 & 9,28 & - \\
Cfru-03(4) & Rata-Rata Panjang Buah (cm) & - & 0,07 & $0,00^{* *}$ & - \\
& P value & 0,69 & 5,94 & 13,15 & 9,25 \\
Cbac-09(S) & Rata-Rata Panjang Buah (cm) & 3,84 & - & $0,00^{* *}$ & $0,00^{* *}$ \\
& P value & - & - & - & - \\
Cchi-03 & Rata-Rata Panjang Buah (cm) & 2,98 & - & - & - \\
& P value & - & - & - & - \\
\hline
\end{tabular}

Keterangan: $\left(^{*}\right)$ : berbeda pada uji t $5 \%,\left(^{* *}\right)$ berbeda pada uji t $1 \%$ antara rata-rata hasil penyerbukan sendiri dan hasil penyerbukan silang antar spesies, (-): tidak ada data 
Tabel 4. Rata-rata diameter buah hasil penyerbukan sendiri dan hasil penyerbukan silang antar spesies.

\begin{tabular}{llcccc} 
& $\begin{array}{c}\text { Cann(B)- } \\
\text { CYM2-151-3 }\end{array}$ & Cfru-03(4) & Cbac-09(S) & Cchi-03 \\
\hline Cann(B)- & Rata-Rata diameter buah (cm) & 1,40 & 1,50 & 1,50 & - \\
CYM2-151-3 & P value & - & 0,14 & 0,17 & - \\
Cfru-03(4) & Rata-Rata diameter buah (cm) & 0,97 & 0,95 & 0,89 & 0,92 \\
& P value & 0,60 & & 0,06 & 0,59 \\
Cbac-09(S) & Rata-Rata diameter buah (cm) & 3,19 & - & - & - \\
& P value & - & - & - & - \\
Cchi-03 & Rata-Rata diameter buah (cm) & 2,15 & - & - & - \\
& P value & - & - & - & - \\
\hline
\end{tabular}

Keterangan: $\left({ }^{*}\right)$ : berbeda pada uji t $5 \%,\left(^{* *}\right)$ berbeda pada uji t $1 \%$ antara rata-rata hasil penyerbukan sendiri dan hasil penyerbukan silang antar spesies, (-) : tidak ada data

Tabel 5. Rata-rata jumlah biji hasil penyerbukan sendiri dan penyerbukan silang antar spesies.

\begin{tabular}{llcccc}
\hline & $\begin{array}{c}\text { Cann(B)- } \\
\text { CYM2-151-3 }\end{array}$ & Cfru-03(4) & Cbac-09(S) & $\begin{array}{c}\text { Cchi- } \\
03\end{array}$ \\
\hline Cann(B)- & Rata-Rata Jumlah Biji & 107 & 97 & 99 & 0,47 \\
CYM2-151-3 & P value & - & 0,30 & 45 \\
Cfru-03(4) & Rata-Rata Jumlah Biji & 37 & 43 & 0,40 \\
& P value & 0,01 & - & \\
& & $*$ & & - \\
& & & & - \\
Cbac-09(S) & Rata-Rata Jumlah Biji & 111 & - & - \\
Cchi-03 & $\begin{array}{l}\text { P value } \\
\text { Rata-Rata Jumlah Biji }\end{array}$ & - & - & - \\
\hline
\end{tabular}

Keterangan: $\left({ }^{*}\right)$ : berbeda pada uji t $5 \%,\left(^{* *}\right)$ berbeda pada uji t $1 \%$ antara rata-rata hasil penyerbukan sendiri dan hasil penyerbukan silang antar spesies, $(-)$ : tidak ada data.

Tabel 6. Rata-rata bobot biji penyerbukan sendiri dan hasil penyerbukan silang antar spesies.

\begin{tabular}{llcccc}
\hline & $\begin{array}{c}\text { Cann(B)- } \\
\text { CYM2-151-3 }\end{array}$ & Cfru-03(4) & Cbac-09(S) & Cchi-03 \\
\hline Cann(B)- & Rata-Rata Bobot Buah (gr) & 0,70 & 0,19 & 0,53 & - \\
CYM2-151-3 & P value & - & $0,000^{* *}$ & $0,003^{*}$ & - \\
Cfru-03(4) & Rata-Rata Bobot Buah (gr) & 0,13 & 0,21 & 0,15 & 0,09 \\
& P value & 0,20 & - & $0,000^{* *}$ & $0,000^{* *}$ \\
Cbac-09(S) & Rata-Rata Bobot Buah (gr) & 0,78 & - & - & - \\
& P value & - & - & - & - \\
Cchi-03 & Rata-Rata Bobot Buah (gr) & 0,14 & - & - & - \\
& P value & - & - & - & - \\
\hline
\end{tabular}

Keterangan: $\left(^{*}\right)$ : berbeda pada uji t $5 \%$, $\left({ }^{* *}\right)$ berbeda pada uji t $1 \%$ antara rata-rata hasil penyerbukan sendiri dan hasil penyerbukan silang antar spesies, (-) : tidak ada data.

Bobot buah yang diperoleh dari hasil penyerbukan persilangan $C$. frutescens (Cfru03(4)) x C. annuum (Cann(B)-CYM2-151-3), C. frutescens (Cfru-03(4) x C. baccatum (Cbac09(S)) dan C. frutescens (Cfru-03(4)) x C. chinense (Cchi-01) memiliki perbedaan yang nyata terhadap bobot buah hasil dari penyerbukan sendiri (Tabel 2). Hasil persilangan C. annuum (Cann(B)-CYM2-151-3) x C. baccatum (Cbac-09(S)), C. frutescens (Cfru03(4)) x C. annuum (Cann(B)-CYM2-151-3), C. frutescens (Cfru-03(4)) x C. chinense (Cchi-01), 
C. frutescens (Cfru-03(4)) x C. baccatum (Cbac09(S)) memiliki perbedaan yang sangat nyata terhadap panjang buah hasil selfing (Tabel 3). Persilangan C. annuum (Cann(B)-CYM2-151-3) x C. frutescens (Cfru-03), C. annuum (Cann(B)CYM2-151-3) x C. baccatum (Cbac-09(S)), C. frutescens (Cfru-03(4)) x C. annuum (Cann(B)CYM2-151-3), C. frutescens (Cfru-03(4)) x C. baccatum (Cbac-09(S)) dan C. frutescens (Cfru03(4)) $x$ C. chinense (Cchi-01) tidak menghasilkan perbedaan diameter buah terhadap hasil selfing (Tabel 4). Perbedaan hasil persilangan interspesifik dapat disebabkan oleh perbedaan genotipe yang disilangkan. Perbedaan karakater yang diperoleh dapat disebabkan oleh faktor genetik dari masingmasing genotipe (Shandila et al., 2017; Waluyo et al., 2018).

Dari Tabel 5 diketahui bahwa rata-rata jumlah biji persilangan C. frutescens (Cfru-03(4)) x C. annuum (Cann(B)-CYM2-151-03) berbeda dari selfing, sedangkan untuk persilangan $C$. annuum (Cann(B)-CYM2-151-3) x C. frutescens (Cfru-03), C. annuum (Cann(B)-CYM2-151-3) x C. baccatum (Cbac-09(S)), C. frutescens (Cfru03(4)) x C. baccatum (Cbac-09(S)) dan C. frutescens (Cfru-03(4)) x C. chinense (Cchi-01) tidak memiliki perbedaan yang terhadap hasil selfingnya. Persilangan yang lain tidak dapat dibandingkan karena tidak ada data. Tidak adanya data disebabkan oleh tidak ada buah yang terbentuk sehingga biji yang dihasilkan pun tidak ada. Salah satu penyebab kegagalan pembentukan buah adalah tidak cocoknya putik dan serbuk sari. Keberhasilan persilangan kerabat jauh sangat tergantung dekat atau tidaknya hubungan yang disilangkan. Semakin jauh hubungan kekerabatan tersebut maka besar kemungkinan untuk terjadi kegagalan (Syukur et al., 2018)

Bobot biji hasil persilangan C. annuum (Cann(B)-CYM2-151-3) x C. frutescens (Cfru-03), C. frutescens (Cfru-03(4)) x C. baccatum (Cbac09(S)), C. frutescens (Cfru-03(4)) x C. annuum (Cann(B)-CYM2-151-3) dan C. frutescens (Cfru03(4)) X C. chinense (Cchi-01) memiliki perbedaan yang sangat nyata terhadap bobot biji hasil selfing (Tabel 6). Hasil lain ditunjukkan dari persilangan $\mathrm{C}$. annuum (Cann(B)-CYM2151-3) x C. baccatum (Cbac-09(S)) memiliki perbedaan bobot biji yang nyata terhadap hasil selfingnya, sedangkan untuk persilangan yang lain tidak dapat dibandingkan karena tidak terdapat data yang diperoleh. Gagalnya pembentukan biji disebabkan terdapat beberapa biji yang infertil diantara persilangan tersebut. Perbedaan karakater yang diperoleh dapat disebabkan oleh faktor genetik dari masingmasing genotipe (Shandila et al., 2017; Waluyo et al., 2018).

\section{Kesimpulan}

Penyerbukan sendiri pada setiap spesies cabai memiliki kompatibilitas penuh dengan persentase pembentukan buah yaitu $100 \%$. Pada persilangan interspesifik memiliki kompatibilitas penuh, sebagian, dan inkompatibilitas, tergantung dari pasangan persilangan interspesifik yang dilakukan.

\section{Ucapan Terima Kasih}

Ucapan terima kasih disampaikan kepada Direktur Agro Techno Park yang telah menyediakan fasilitas penelitian di Seed and Nursery Industry, dan kepada seluruh pihak yang telah membantu dalam penelitian ini.

\section{Daftar Pustaka}

Agustina, N.I., and B. Waluyo. 2017. Keragaman Karakter Morfo-Agronomi dan Keanekaragaman Galur- galur Cabai Besar ( Capsicum annuum L.). J. Agro 4(2): 120130. doi: $10.15575 / 1608$.

Arnason, A. 2019. Bell Peppers 101: Nutrition Facts and Health Benefits. Healthline. https://www.healthline.com/nutrition/fo ods/bell-peppers\#benefits.

Barchenger, D.W., and P.W. Bosland. 2019. North American crop wild relatives. North Am. Crop Wild Relat. Vol. 2 2(7): 225-242. doi: 10.1007/978-3-319-97121-6.

FAO. 2019.2 Crop. http://www.fao.org/faostat/en/\#data/Q $\mathrm{C} /$ visualize.

Fehr, W. 1991. Principle of Cultivar Development: Theory and Technique. Volume 1. Macmillan Publishing Company, America.

Fehr, W., and H.. Hadley. 1980. Hybridization of Crop Plants. American Society of Agronomy and Crop Science Society of 
America, Publishers, Madisom, Wisconsin, USA.

Kantar, M.B., J.E. Anderson, S.A. Lucht, K. Mercer, V. Bernau, et al. 2016. Vitamin variation in Capsicum Spp . provides opportunities to improve nutritional value of human diets. PLoS One 11(8): 1-12. doi: 10.1371/journal.pone.0161464.

Martins, K.C., T.N.S. Pereira, S.A.M. Souza, R. Rodrigues, and A.T. do Amaral Junior. 2015. Crossability and evaluation of incompatibility barriers in crosses between capsicum species. Crop Breed. Appl. Biotechnol. 15(3): 139-145. doi: 10.1590/1984-70332015v15n3a25.

Nascimento, N.F.F., M.F. Nascimento, E.R. Rêgo, J.A.M. Lima, M.M. Rêgo, et al. 2015. Intraspecific croß-compatibility in ornamental pepper. Acta Hortic. 1087: 339344. doi: 10.17660/ActaHortic.2015.1087.44.

do Rêgo, E.R., M.M. do Rêgo, C.D. Cruz, F.L. Finger, and V.W.D. Casali. 2011. Phenotypic diversity, correlation and importance of variables for fruit quality and yield traits in Brazilian peppers (Capsicum baccatum). Genet. Resour. Crop Evol. 58(6): 909-918. doi: 10.1007/s10722010-9628-7.

Rochayat, Y., and V.R. Munika. 2015. Respon kualitas dan ketahanan simpan cabai merah ( Capsicum annuum L.) dengan penggunaan jenis bahan pengemas dan tingkat kematangan buah. Kultivasi 14(1): 65-72. doi: 10.24198/kultivasi.v14i1.12093.

Shandila, P., N.I. Agustina, P. Kurniawan, D. Saptadi, and B. Waluyo. 2017. Potensi Hasil Buah dan Biji Galur-Galur Potensial Sebagai Sumber Benih Untuk Calon Varietas Cabai Bersari Bebas. p. 75-82

Shandila, P., B. Waluyo, and A.L. Adiredjo. 2019.
Evaluasi kemajuan genetik seleksi langsung dan tidak langsung melalui komponen hasil beberapa galur cabai besar (Capsicum annuum L.). J. Produksi Tanam. 7(1): 90-97.

Syukur, M., S. Sujiprihati, and R. Yunianti. 2018. Teknik Pemuliaan Tanaman (S. Nugroho and Febriani, editors). 3rd ed. Penabur Swadaya Grup, Jakarta.

Undang, M. Syukur, and Sobir. 2015. Identifikasi spesies cabai rawit (Capsicum spp.) berdasarkan daya silang dan karakter morfologi. J. Agron. Indones. (Indonesian J. Agron. 43(2): $118 . \quad$ doi: 10.24831/jai.v43i2.10413.

Waluyo, B., D. Saptadi, N.R. Ardiarini, P. Shandila, N.I. Agustina, et al. 2018. Seleksi galur-galur cabai berdasarkan penampilan penciri spesifik karakter agronomi dengan biplot analisis komponen utama. In: Hayati, P.K.D., Sutoyo, and Fadli, M., editors, Prosiding Seminar Nasional Perhimpunan Ilmu Pemuliaan Indonesia (Peripi): Kedaulatan Benih Menuju Lumbung Pangan Dunia 2045. LPTIK Universitas Andalas. p. 237-244

Waskito, H., A. Nuraini, and N. Rostini. 2018. Respon pertumbuhan dan hasil cabai keriting ( Capsicum annuum L.) CK5 akibat perlakuan pupuk npk dan pupuk hayati. Kultivasi 17(2): 676-681. doi: 10.24198/kultivasi.v17i2.17856.

Yoon, B., C.Y. Dong, W. Do Jae, and G.P. Hyo. 2006. Overcoming two post-fertilization genetic barriers in interspecific hybridization between Capsicum annuum and C. baccatum for introgression of anthracnose resistance. Breed. Sci. 56(1): 31-38. doi: 10.1270/jsbbs.56.31. 